\title{
Thermo-Stable Alkaline Protease Purified from a Novel Endophyte Brevundimonas diminuta VKB1 Hosted in Carica papaya L. - Production Enrichment Approach
}

\author{
Divya Gopalakrishnan ${ }^{1}$ (D), Venkat Kumar Shanmugam ${ }^{2, *}$ (D) \\ 1 Vellore Institute of Technology; diviya.pavithra@gmail.com (D.G.); venkatkumars@vit.ac.in (V.K.S.); \\ * Correspondence e-mail: venkatkumars@ vit.ac.in (V.K.S.)
}

Scopus Author ID 51462272000

Received: 3.02.2021; Revised: 2.03.2021; Accepted: 4.03.2021; Published: 10.03.2021

\begin{abstract}
Protease is the central component of enzymes in all lives, from microbes to humans. Their limited applications in the medicinal field demand their need for higher production. Our study enlightens protease's sustainable production using various optimization techniques and purification of the protease purified from Carica papaya L's endophytes. The results depict that the protease synthesis was enhanced to five-fold concentration after optimization of the production media. The purified protease was a single protein showing high stability towards alkaline $\mathrm{pH}$ and thermo-stable. The metal ions' influence indicates that the protease can be catalyzed highly in the presence of copper, magnesium, iron atoms. Results disclose the purified protease further can be taken for pharmacological studies to understand their efficiency as a therapeutic regime.
\end{abstract}

Keywords: endophyte; protease; Placket-Burman; response surface methodology; purification.

(C) 2021 by the authors. This article is an open-access article distributed under the terms and conditions of the Creative Commons Attribution (CC BY) license (https://creativecommons.org/licenses/by/4.0/).

\section{Introduction}

Symbiotic growth of microbes inside the host plant without affecting them are termed endophytes. These symbiotic interactions were highly facilitated by the extracellular enzyme produced by these microbes. It was also reported that the enzymes also inhibit many plant pathogens and withstand biotic stress. Hence the capability of endophytes living together with host and synergistic production of these enzymes helps counteract emerging issues. Further, these extracellular enzymes can be taken for various large-scale fermentation studies, as they adapt extremely to various environmental conditions [1,2]. Some examples of bacterial endophytes from Rhizophoraceae [3], Acanthaceae [4], and various mangrove plants [5] have exhibited significant enzyme activity. Also, it has the capability of producing rare enzymes such as L-Asparaginase [6], heat liable glucoamylase [7], and fibrin degrading protease [8,9].

Carica papaya $\mathrm{L}$. is a fruit that is extensively grown in the region of tropical and subtropical environments [10]. The latex and unripe fruit are rich in protease enzymes like papain, chemo papain, peptidase A and B, lysozymes [11,12]. Though it is a pack of enzymerich fruit, researchers restricted it to the limit of purifying the papain, a well-known protease enzyme [13,14]. Also, the production of the inactive form of protease, low purification yield, production based on varieties, wastage of fruits is some of the drawbacks that limit the enzyme production and purification $[15,16]$. In an alternative method of enzyme purification, microbes residing inside the fruit termed endophytes can be isolated and identified for further studies. Studies reported that strains isolated from Carica papaya L. exhibited predominantly Bacillus 
species followed by other bacterial species such as Kocuria, Acinetobacter, Staphylococcus, and Enterobacter. They can produce various extracellular enzymes like amylase, protease, pectinase, cellulase, etc. [11].

Hydrolytic enzymes are the central components found in all animals, plants, humans, and microbes; they cleave peptide bonds of a long polypeptide amino acid chain through the hydrolysis process. The degradative nature derives protein modification based on their selectivity and specificity of the enzyme as they contribute $60 \%$ worldwide application in industrial sectors. Microbial source of protease purified in a shorter time with high substrate specificity and catalytic activity [17,18]. Hence many industrial and biotechnological sectors concentrate on the microbial enzyme production that replaces or rejuvenates the host enzyme activity. The active therapeutic proteases have been in research based on their diversity and specificity. Depletion in the body enzyme leads to several pains, injuries, inflammation, and diseases. The underlying cause of many unexplored health issues paved the way for developing novel enzymes [19].

Hence, the study's insight relies on identifying and screening protease-producing endophytic bacteria from the host Carica papaya L. Substantial increment of the enzyme production was obtained using statistical optimization techniques Placket-Burman and response surface methodology designs. Further enzyme purification was carried out under the optimized medium condition, and various biochemical characterization was performed to understand its stability and molecular weight.

\section{Materials and Methods}

\subsection{Sample collection.}

The unripe Carica papaya L. (Papaya) was collected from the tree near the Vellore Institute of Technology, Vellore.

\subsection{Surface sterilization.}

Surface sterilization was carried out by a continuous tap water wash followed by rinsing in $70 \%$ ethanol for one minute. Further, the sample was soaked in a $0.1 \%$ Sodium Hypochlorite solution containing $1 \%$ tween-20 surfactant for four minutes to remove cell debris and other microbes. Then the sample was rinsed and washed thrice in sterilized double-distilled water. The third time used water was taken as a positive control for analyzing sterilization quality [20].

\subsection{Isolation of bacterial samples from the surface-sterilized papaya.}

The isolation procedure was carried out by the impregnation method. The surfacesterilized sample was made into small pieces using a sterilized knife. For the impregnation method, the endocarp region was placed in contact with the nutrient agar medium. The plates were incubated for seven days at $37^{\circ} \mathrm{C}$. Colonies; specifically, bacterial cultures were identified based on their distinct shape, size, and color and separately pure cultured for further screening [20,21]. 


\subsection{Qualitative selection of protease producing bacteria.}

The selection of strains based on their enzyme activity was carried out before strain identification using the skim milk agar test. The isolate VKB1 that is exhibiting the maximum zone of degradation was taken for further studies.

Bacterial cultures were inoculated as a single streak on skimmed milk agar plates containing (g/l) peptone, 1; glucose, 1; beef extract, 5; skim milk powder, 8; and agar, 15. The appearance of a zone of degradation was found in plates after following the incubation for two days at $37^{\circ} \mathrm{C}$. Strains showing the degradation of casein by forming a clear zone were taken for fibrin plate assays [22,23].

\subsection{Molecular and morphological characterization of bacteria.}

The screened-out bacteria were chosen for their species identification using morphological, biochemical, and molecular characterization. Genomic DNA of the selected strain was extracted from cells of a $24 \mathrm{~h}$ culture. The $16 \mathrm{~S}$ rDNA sequencing of the selected strain was PCR amplified using universal primers using ABI VERTIC thermocycler. The PCR product was purified with a base pair of approximately $1777 \mathrm{bp}$ were sequenced using the upstream primer $27 \mathrm{~F}$ and downstream primer 1492R. Samples were performed with PCR analysis using the ABI PRISM ${ }^{\circledR}$ BigDyeTM terminator cycle kit. The product resulted were electrophoresed in an ABI3730XL automated DNA sequencing system. Then the obtained nucleotides were subjected to a homology search using the National Centre for Biotechnology (NCBI) BLAST program [24]. The obtained sequence was submitted to GenBank.

\subsection{Factors influencing protease production under submerged fermentation.}

Submerged fermentation for protease production is preferred due to its advantages, such as consistency in enzyme characteristics, effortless downstream approach, and processing conditions. Hence studies have focused on process development and scale-up of the protease purification under optimized physical parameters and nutrient factors [25-28]. The variables of each factor influencing protease synthesis in the bacteria were selected based on the onefactor at a time approach (OFAT). Physical parameters such as $\mathrm{pH}(4,6,7,8,9,12)$, RPM (50, $100,150,200)$, fermentation period $(12,24,36,48,60,72,84,96)$, temperature $(4,25,37,45$, $60\left({ }^{\circ} \mathrm{C}\right)$ ) was studied. Similarly, nutrient factors such as carbon source (Dextrose, Maltose, Xylose, Sucrose, Starch and Galactose), organic nitrogen source (Yeast Extract (YE), Beef Extract (BE), Casein, Peptone, Urea, and Gelatin) inorganic nitrogen source (Ammonium Chloride, Sodium Carbonate, Sodium di-hydrogen Phosphate, Potassium di-hydrogen Phosphate, and Ammonium Sulphate) was analyzed. All the optimization was carried out in triplicates. The mean value was taken for the estimation of enzyme activity by the following protease assay. With some modifications in the experiment, the casein solution $(2.5 \mathrm{~mL}, 1.2 \%$ w/v) was mixed with the crude enzyme dissolved in $2.5 \mathrm{~mL}$ of the $0.1 \mathrm{M}$ Tris- $\mathrm{HCl}$ buffer $(\mathrm{pH}$ 7.8) incubated for $30 \mathrm{~min}$ at $37^{\circ} \mathrm{C}$. Further, the reaction was stopped by adding $5 \mathrm{~mL}$ of trichloroacetic acid $(0.11 \mathrm{M})$ containing sodium acetate $(0.22 \mathrm{M})$ and acetic acid $(0.33 \mathrm{M})$. Precipitation of the remaining protein was centrifuged at $10000 \mathrm{rpm}$ for $10 \mathrm{mins}$, and the samples were measured at $275 \mathrm{~nm}$ against Tris- $\mathrm{HCl}$ as blank [29]. Total protein estimation was carried out by the Lowrys method [30]. 


\subsection{Statistical optimization for improvised enzyme yield.}

The major drawback of the traditional OFAT approach is difficulty analyzing the optimal conditions resulting from the interaction among different enzyme synthesis factors. Other disadvantages are time-consuming and expensive in screening out the variables out of substantial experimental factors. Hence, to eliminate these difficulties, experimental factorial design and response methodology can be used for medium optimization [2,31,32].

The experimental factorial design, such as Plackett-Burman (PB) design, helps select significant factors from many fermentation variables. Further, the results from this design are used in the collection of variables in further optimization. Response surface methodology (RSM) guides in designing experiments, building models, evaluating the effects of different factors, and searching the optimal conditions upon the interaction of various factors for the desired enzyme activity [33-35].

\subsubsection{Significant variable analysis using Plackett-Burman design approach.}

Plackett-Burman's (PB) factorial design was used to screen the significant factors that are affecting the production of a protease by the strain. A total of six factors was selected from the OFAT approach for the experiment that includes maltose as a carbon source, yeast extract as a nitrogen source, sodium di-hydrogen phosphate as an inorganic nitrogen source, $72 \mathrm{~h}$ of the fermentation period, $\mathrm{pH}$, and rate of agitation (Table 1). Based on the PB design, every selected factor was analyzed at two levels: lower level (-1) and higher level (+1). The list of factors and levels were given in Table 1.

Table 1. Factors selected for Plackett-Burman design.

\begin{tabular}{l|l|l|l}
\multirow{2}{*}{ Factors } & Units & Coded levels \\
\cline { 3 - 4 } & & Low & High \\
\hline Maltose (A) & $\%(\mathrm{w} / \mathrm{v})$ & 0.5 & 1 \\
\hline Yeast Extract (B) & $\%(\mathrm{w} / \mathrm{v})$ & 0.1 & 1 \\
\hline $\mathrm{NaH}_{2} \mathrm{PO}_{4}(\mathrm{C})$ & $\%(\mathrm{w} / \mathrm{v})$ & 0.05 & 0.25 \\
\hline $\mathrm{pH}(\mathrm{D})$ & & 4 & 9 \\
\hline Fermentation period & $\mathrm{H}$ & 72 & 96 \\
\hline Agitation & $\mathrm{rpm}$ & 100 & 150
\end{tabular}

The experimental design is based on the first-order polynomial model:

$Y=\beta_{0}+\sum \beta_{i} X_{i}$

where $\mathrm{Y}$ is the response activity (total enzyme activity in $\mathrm{U} / \mathrm{mL}$ ), $\beta_{0}$ termed model intercept, and $\beta_{\mathrm{i}}$ is the linear coefficient, and $\mathrm{X}_{\mathrm{i}}$ is the level of the independent variable. Though the model does not explain the interaction between factors, it evaluates the significant factors that influence the response. All the design experiments were performed in triplicates, and their average enzyme activity was taken as a response (Y). All the calculation of statistical analysis was performed using Analysis of Variance (ANOVA) and the significant factors ( $<$ 0.05$)$ for the protease production were optimized using response surface methodology (RSM). All the experiments were carried out using statistical software, Design-Expert 10 [36]. 
2.7.2. Optimization using response surface methodology: central composite design approach.

The response surface methodology (RSM) was performed to analyze the effects of selected variables on the protease yield. Three independent variables (yeast extract, $\mathrm{pH}$, and fermentation period) were selected for the central composite design (CCD) of RSM to estimate the relative significance of the factors even in their complex interactions (Table 2). Selected main factors were studied at five different levels $(-\alpha,-1,0,+1$, and $+\alpha)$ in a set of twenty experiments that includes eight factorial, six axial, and six center points.

Table 2. Individual variables and their coded values for central composite design.

\begin{tabular}{|c|c|c|c|c|c|c|}
\hline \multirow[t]{2}{*}{ Factors } & \multirow[t]{2}{*}{ Units } & \multicolumn{5}{|c|}{ Coded levels } \\
\hline & & $-\alpha$ & -1 & $\mathbf{0}$ & +1 & $+\alpha$ \\
\hline Yeast Extract & $\%(\mathrm{w} / \mathrm{v})$ & -0.206807 & 0.1 & 0.55 & 1 & 1.30681 \\
\hline $\mathrm{pH}$ & & 2.29552 & 4 & 6.5 & 9 & 10.7045 \\
\hline Fermentation period & $\mathrm{h}$ & 63.8185 & 72 & 84 & 96 & 104.182 \\
\hline
\end{tabular}

The experimental design data were evaluated as a second-order polynomial regression equation comprising both individual and combinatorial effects of each variable.

$Y=a_{0}+\sum_{i=1}^{3} a_{i} C_{i}+\sum_{i=1}^{3} a_{i i} C_{i}^{2}+\sum_{i=1}^{2} \sum_{j=i+1}^{3} a_{i j} C_{i j}$

where $\mathrm{Y}$ is the experimental and predicted response, $a_{0}$ is the offset term, $a_{i}, a_{i i}$ and $a_{i j}$ are the coefficients of linear terms, square terms, and the interactive terms, respectively and $C_{i}$ 's were $\mathrm{A}, \mathrm{B}$, and $\mathrm{C}, C_{i j}$ 's are $\mathrm{AB}, \mathrm{BC}$, and $\mathrm{CA}$. All the experiments were performed in duplicates, and the mean proteolytic activity $(\mathrm{U} / \mathrm{mL})$ was taken as a response $(\mathrm{Y})$.

ANOVA was done to estimate the model. The Values of "Prob $>$ F" $(<0.05)$ indicated that the model factors were significant. The fitted polynomial equation was given as $3 \mathrm{D}$ surface plots to view the relationship between the responses and each factor's levels in the design. The combinatorial effect of each optimized parameter that gave maximum enzyme activity (Y) was tested experimentally to confirm the model's validity $[37,38]$.

\subsection{Separation and purification of protease.}

Based on the optimized parameters, the production medium was modified, and the culture was mass-produced. After incubation, the medium with culture was centrifuged, and the cell-free supernatant was collected. The crude enzyme was subjected to ammonium sulfate precipitation with $60 \%$ saturation. The enzyme salt mixture was left overnight at $4^{\circ} \mathrm{C}$, and then the protein precipitate was separated by centrifugation at $10000 \mathrm{rpm}$ for $10 \mathrm{~min}$. The pellet was collected and dissolved in $2 \mathrm{~mL}$ of $0.02 \mathrm{M}$ Tris- $\mathrm{HCl}(\mathrm{pH} 7.8)$, desalted with a dialysis bag with the same buffer at $4^{\circ} \mathrm{C}$ overnight. The obtained dialysis fraction was concentrated by lyophilization. The lyophilized sample was resuspended in $0.02 \mathrm{M}$ of Tris-HCl buffer ( $\mathrm{pH} 7.8$ ). The resuspended sample was loaded onto a DEAE-Cellulose column, and the protein samples were eluted by sequential extraction with the same buffer with a gradient increase in $\mathrm{NaCl}$ concentration $(0 \mathrm{M}$ to $1 \mathrm{M})$. All the samples from each fraction were measured with the protease activity were pooled together. The pooled-out samples were dialyzed again with Tris$\mathrm{HCl}$ buffer ( $\mathrm{pH} 7.8$ ), then lyophilized and resuspended in the same buffer for gel filtration chromatography. Lyophilized and the concentrated sample was applied to the Sephadex G100 column pre-equilibrated and eluted (at a flow rate of $30 \mathrm{~mL} / \mathrm{h}$ ) with $0.5 \mathrm{M}$ of Tris $\mathrm{HCl}$ 
containing $0.15 \mathrm{M} \mathrm{NaCl}$. Active fractions were collected and pooled together after protease analysis and protein concentration determination. The pooled fractions were lyophilized and stored at $-20^{\circ} \mathrm{C}$ for further characterization $[24,39,40]$.

\subsection{HPLC analysis.}

The lyophilized purified sample obtained from gel filtration chromatography was dissolved in $20 \mathrm{mM}$ of Tris- $\mathrm{HCl}$ buffer ( $\mathrm{pH} \mathrm{7.8)} \mathrm{and} \mathrm{analyzed} \mathrm{for} \mathrm{purity} \mathrm{using} \mathrm{High-}$ Performance liquid chromatography equipped with C18 column, UV Detector-2487 (Waters HPLCPump-1525, Milford, MA, USA). The mobile phase was water and acetonitrile in the ratio $1: 1$. The purity was authenticated at $280 \mathrm{~nm}$ [41].

\subsection{SDS-PAGE.}

The purified sample was subjected to analyze the mass and purity by SDS-PAGE (12\% $[\mathrm{w} / \mathrm{v}])$. The purified proteins were loaded onto gels after being heated in an SDS sample buffer. The molecular weight was determined using a wide range of protein markers (Genei, Bangalore). The protein bands were visualized by performing a silver stain method $[27,42]$.

\subsection{Biochemical characterization of the purified enzyme.}

The effect of $\mathrm{pH}$ on the extracellular protease was studied with varying $\mathrm{pH}$ ranging

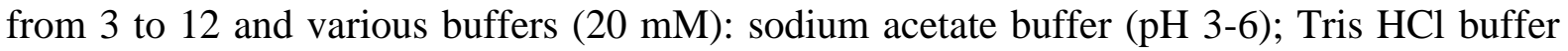
(6.5-8.8); Phosphate buffer (9-12). The enzyme activity was estimated by performing the protease assay after incubating the purified enzyme in all the buffer $\mathrm{pH}$ ranging from 3 to 12 for four hours at room temperature. Similarly, the effect of temperature was also studied by incubating the purified protein at a different temperature ranging $\left(4,25,37,45\right.$, and $\left.60{ }^{\circ} \mathrm{C}\right)$ for four hours for the stability analysis, and the enzyme assay was performed. Various inhibitors: PMSF, DTPA, EDTA, and metal ions: $\mathrm{MgSO}_{4}, \mathrm{MnSO}_{4}, \mathrm{CuSO}_{4}, \mathrm{ZnSO}_{4}, \mathrm{FeSO}_{4}$, and $\mathrm{CaCl}_{2}$ at a concentration of $5 \mathrm{mM}$ was mixed with one $\mu \mathrm{g}$ of the purified enzyme and incubated for two hours and their enzyme activity was evaluated. The evaluated enzyme activity was reported as the percentage residual activity $[40,43,44]$

\section{Results and Discussion}

\subsection{Isolation and screening of endophytes for protease activity.}

The study revealed that the unripe papaya was enriched with various beneficial endophytic bacteria.

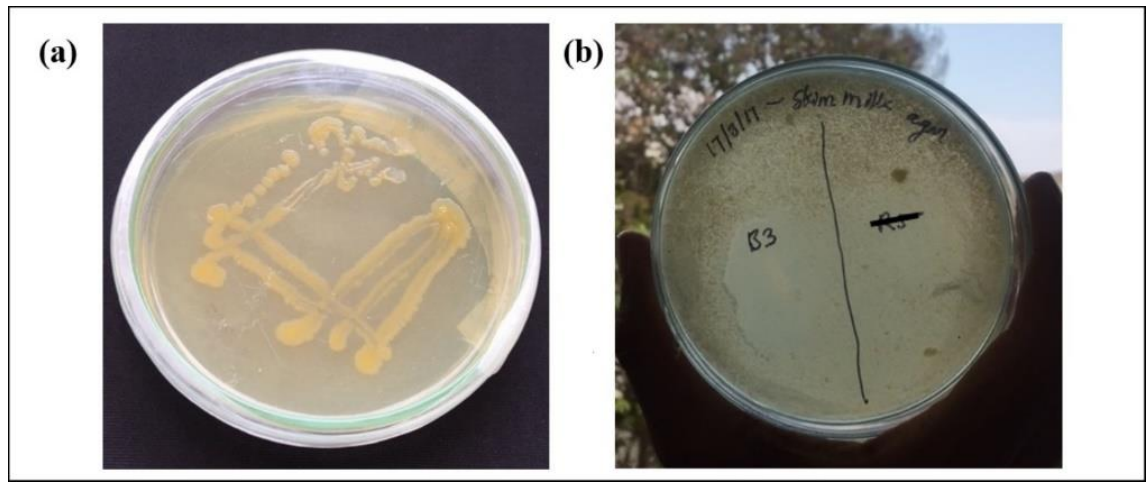

Figure 1. Endophytic bacterium purified and screened for its protease production. (a) Streak culture of the pure cultured endophytic bacterium VKB1; (b) zone of degradation in skim milk agar to screen protease activity. 
Around fifteen colonies were isolated from the endocarp region. The control plates without bacterial colonies define that the isolated colonies are endophytes. All the isolates were screened for protease activity qualitatively using the skim milk agar test. Out of all the strains, VKB1 (Figure 1 (a)) has exhibited good extracellular protease activity by degrading the casein in the skim milk agar plate (Figure 1 (b)).

\subsection{Strain identification.}

The morphological characterization using gram staining concluded that the selected strain VKB1 is a gram-negative bacterium. Further biochemical characterization depicts that the bacteria can hydrolyze casein and gelatin. It also illustrates that the VKB1 strain can produce other enzymes such as catalase, oxidase, etc. The strain VKB1 was further confirmed as Brevundimonas diminuta based on its 16s rRNA sequence and named Brevundimonas diminuta VKB1. The 1239 bp 16s rRNA sequence of Brevundimonas diminuta VKB1 was submitted in the GenBank database and assigned with an accession number MN744337.1 (Figure 2). The detailed evolutionary relationship between the strain VKB1 and other closely related Brevundimonas species families.

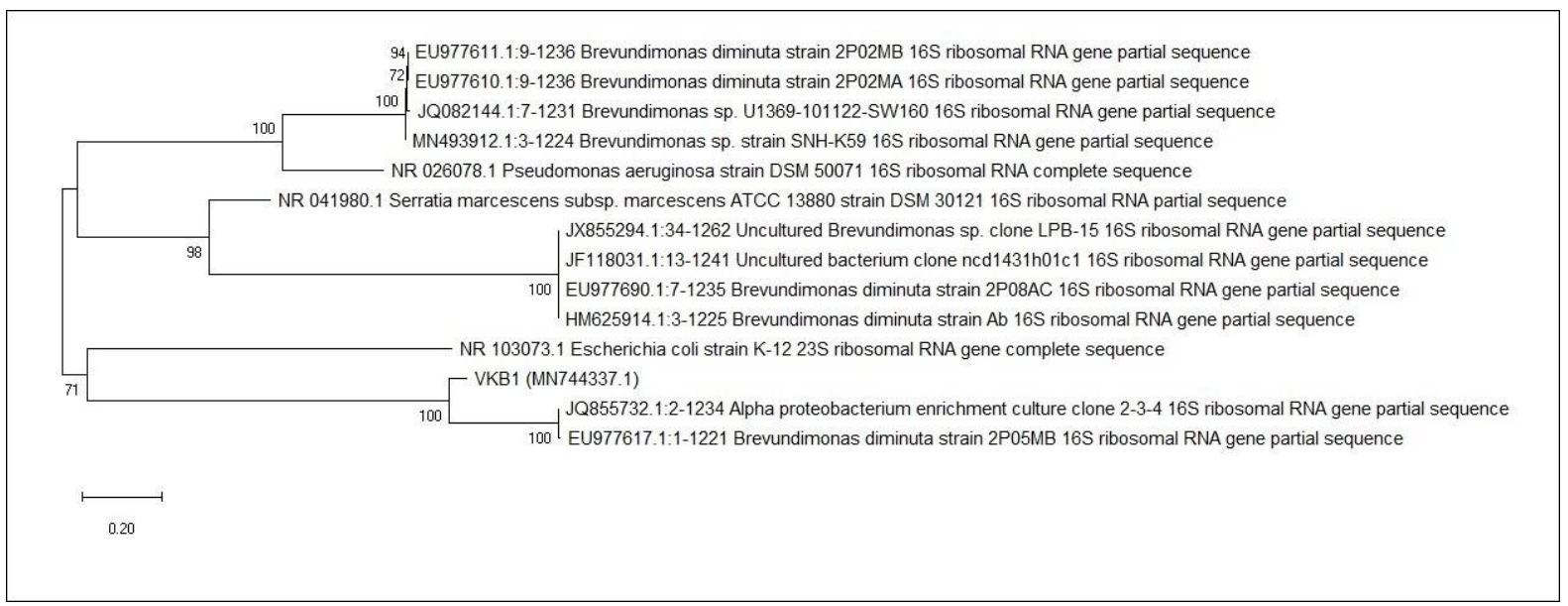

Figure 2. Phylogenetic tree constructed based on the 16s rRNA sequence showing that the strain VKB1 is closely related to Alpha-proteobacterium and Brevundimonas diminuta strain. Escherichia coli strain (K-12,

NR103073.1) and Serratia marcescens strain (DSM 30121, NR041980.1) were used as an outgroup.

\subsection{Preliminary screening of parameters using OFAT.}

Understanding the protease's kinetics and catalytic mechanisms from a new microbe is crucial due to their distinct nature in genetics, metabolic, and enzyme production pathways[45]. It is necessary to understand the influence of physical and nutrient parameters for the fermentation and production of an enzyme [27,36]. A set of OFAT approach experiments was performed to establish a cost-effective and cheap formulation of media for protease production. The extracellular protease synthesis from a bacterium doesn't depend only on the carbon and nitrogen sources but other physical factors such as Incubation time, temperature, $\mathrm{pH}$, and agitation. Studies reported that the alkaline $\mathrm{pH}$ and optimal temperature between 30 to $70{ }^{\circ} \mathrm{C}$ influence the production of protease at a higher concentration $[28,46]$. The synthesis of protease by the endophyte VKB1 was highly influenced by the nutrient factors' maltose, yeast extract, and sodium dihydrogen phosphate (Figure 3 ) that has grown at $37^{\circ} \mathrm{C}$ for $72 \mathrm{~h}$ under an alkaline condition of $\mathrm{pH} 8$. Hence these parameters were chosen for further optimization in $\mathrm{PB}$ design for protease production. 


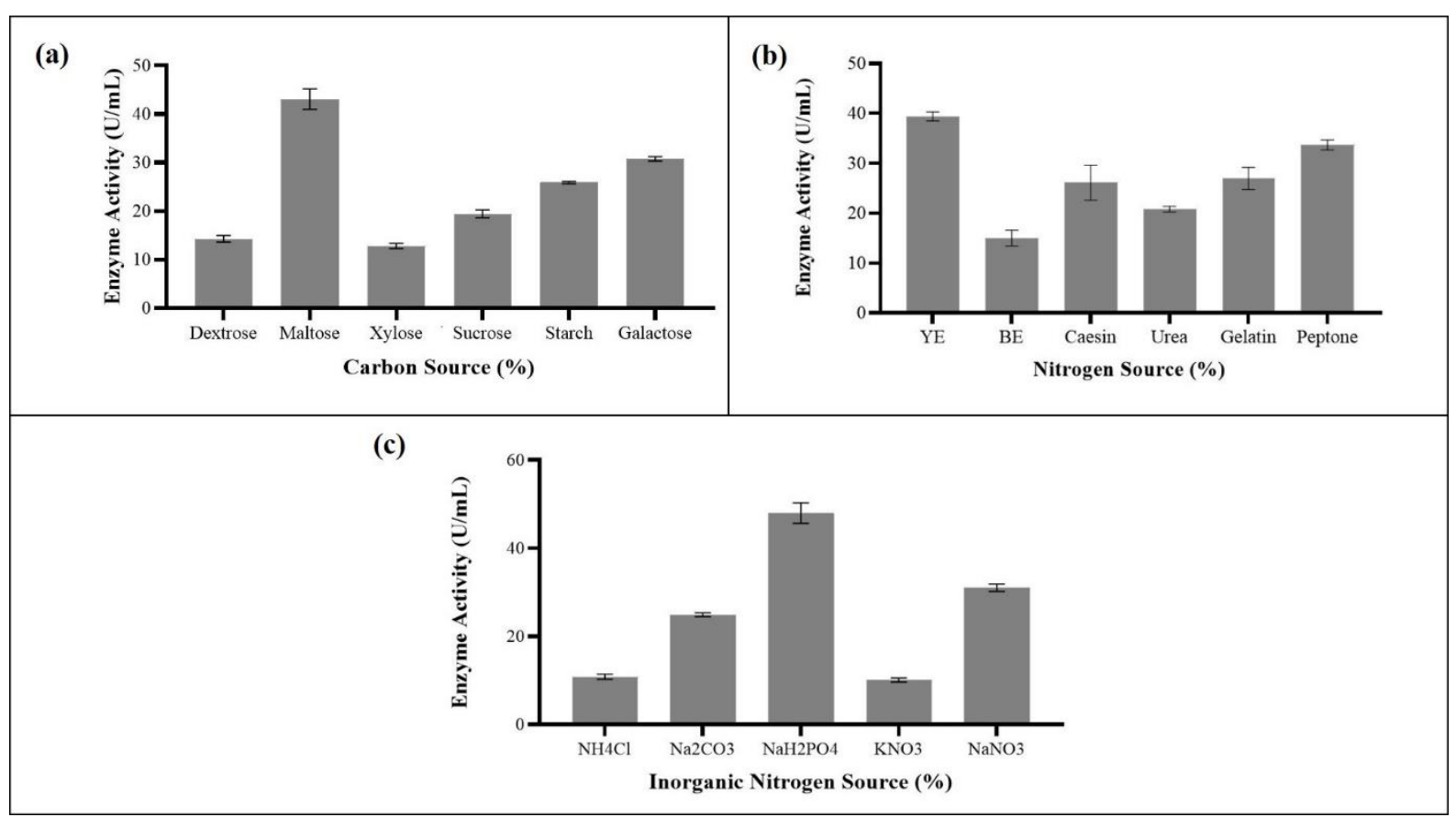

Figure 3. Effects of different carbon and nitrogen sources at an optimum condition $\left(37^{\circ} \mathrm{C}\right.$ and $\mathrm{pH} 7$ with 100 $\mathrm{rpm})$.

\subsection{Selection of significant factors using the PB design.}

Totally six factors were analyzed for their influence on the extracellular protease synthesis using PB design. The PB design matrix for evaluating effective variables in the enzyme production and their response $(\mathrm{Y})$ is given in Table 3.

Table 3. Design model and response (Y) for the Plackett-Burman design.

\begin{tabular}{c|c|c|c|c|c|c|c} 
Run & Maltose & $\begin{array}{c}\text { Yeast } \\
\text { Extract }\end{array}$ & $\mathbf{N a H} \mathbf{P o 4}$ & $\mathbf{p H}$ & $\begin{array}{c}\text { Fermentation } \\
\text { Period }\end{array}$ & Agitation & Enzyme Activity (U/mL) \\
\hline 1 & 1 & 1 & 0.05 & 4 & 72 & 100 & 333.52 \\
\hline 2 & 0.5 & 0.1 & 0.25 & 9 & 72 & 150 & 261.38 \\
\hline 3 & 0.5 & 1 & 0.05 & 9 & 96 & 150 & 820.31 \\
\hline 4 & 1 & 0.1 & 0.05 & 4 & 96 & 150 & 361.67 \\
\hline 5 & 1 & 0.1 & 0.25 & 9 & 96 & 100 & 505.18 \\
\hline 6 & 0.5 & 1 & 0.05 & 9 & 96 & 100 & 688.62 \\
\hline 7 & 1 & 1 & 0.25 & 4 & 96 & 150 & 688.62 \\
\hline 8 & 1 & 0.1 & 0.05 & 9 & 72 & 150 & 401.66 \\
\hline 9 & 0.5 & 0.1 & 0.05 & 4 & 72 & 100 & 260.34 \\
\hline 10 & 0.5 & 1 & 0.25 & 4 & 72 & 150 & 291.95 \\
\hline 11 & 1 & 1 & 0.25 & 9 & 72 & 100 & 542.94 \\
\hline 12 & 0.5 & 0.1 & 0.25 & 4 & 96 & 100 & 134.18
\end{tabular}

The fitness of the model and their significant effect were calculated using the student's t-test ANOVA. Factors that are showing a low $p$-value $(\mathrm{p}<0.05)$ are the significant variables for the enzyme production, and they were selected for subsequent optimization studies. Hence significant variables like Yeast extract (B), $\mathrm{pH}(\mathrm{D})$ and Fermentation period (F) shows p-value of $0.0099,0.0265$ and 0.0461 respectively comparing maltose (A) $(0.3188), \mathrm{NaH}_{2} \mathrm{PO}_{4}(\mathrm{C})$ (0.2599) and agitation (F) (0.3188). The main effect of the medium components, the ANOVA, regression coefficient, $F$ values, a p-value of the variables are shown in Table 4.

Table 4. ANOVA for selected Plackett-Burman design.

\begin{tabular}{l|l|l|l|l|l|l} 
Source & Sum of Squares & df & Mean Square & F Value & Prob > F & \\
\hline Model & 4085.51 & 3 & 1361.84 & 7.73 & 0.0095 & significant \\
\hline B-Yeast Extract & 1990.48 & 1 & 1990.48 & 11.30 & 0.0099 & \\
\hline D-pH & 1298.13 & 1 & 1298.13 & 7.37 & 0.0265 &
\end{tabular}




\begin{tabular}{l|l|l|l|l|l|l}
\hline Source & Sum of Squares & df & Mean Square & F Value & Prob $>$ F & \\
\hline E-Fermentation Period & 796.91 & 1 & 796.91 & 4.52 & 0.0461 & \\
\hline Residual & 1409.38 & 8 & 176.17 & & & \\
\hline Cor Total & 5494.89 & 11 & & & &
\end{tabular}

The model F-value 7.73 implies that the models are significant, and there is only a 0.95 $\%$ chance that an F-value this large could occur due to noise. The "Predicted R-squared" of 0.4229 is in reasonable agreement with the "adjusted R-squared" of 0.6473 . Adequate precision measure the signal-to-noise ratio. A ratio greater than four is desirable. In this model, the adequate ratio is 8.203. Hence the final first-order regression equation derived in terms of coded factors for this experimental model revealed the yield of protease production.

$$
\text { Enzyme Activity }=+147.61+12.88 * \mathrm{~B}+6.24 * \mathrm{D}+8.15 * \mathrm{E}
$$

From the analysis of protease production under the PB design method, it is revealed that both nutrient and physical factors play a role in the influence of protease production. Significant factors and their positive effect were selected for the CCD analysis to understand their specific effects on enzyme production's combinatorial range.

\subsection{Central composite design - response surface methodology.}

CCD was used for the optimization and interaction of three variables such as yeast extract, $\mathrm{pH}$, and fermentation period each were studied at five coded levels of $(-\alpha,-1,0,+1$, and $+\alpha$ ) as shown in Table 2. The models were performed in twenty different runs (Table 5). The maximum enzyme activity of $678.17 \mathrm{U} / \mathrm{mL}$ was observed at run 15 . The results from the design were calculated using ANOVA. P-value $=<0.0001$ shows that the model is significant (Table 6). Also, there is only a $4.16 \%$ chance that this large F-value could occur due to noise. According to the model and ANOVA experimentation, it was observed that the A, B, C, AB, $\mathrm{BC}, \mathrm{AC}, \mathrm{A}^{2}, \mathrm{~B}^{2}$, and $\mathrm{C}^{2}$ are important terms. The second-order polynomial models were used to relate the independent variables with enzyme activity. The calculated coefficient of determination $\left(\mathrm{R}^{2}\right) 0.9998$ indicates that the model could describe $91 \%$ of the variability. The "lack of fit F value" of 0.718 shows the lack of fit is not significant relative to the pure error determining that the non-significant lack of fit value is good. The signal-to-noise ratio was measured using adequate precision, which should be greater than 4 . In this model, the ratio is 193.623 indicates an adequate signal, and therefore, the model is significant for the enzyme bioprocess.

Table 5. Experimental design and response ( $\mathrm{Y}$ ) for central composite design.

\begin{tabular}{|c|c|c|c|c|c|c|c|}
\hline \multirow[t]{2}{*}{ Run } & \multirow[t]{2}{*}{ Yeast Extract } & \multirow[t]{2}{*}{ pH } & \multirow[t]{2}{*}{ Fermentation period } & \multicolumn{4}{|c|}{ Response (Y) } \\
\hline & & & & \begin{tabular}{|l|} 
Enzyme \\
(U/mL)
\end{tabular} & Activity & $\begin{array}{l}\text { Predicted } \\
\text { (U/mL) }\end{array}$ & Activity \\
\hline 1 & \begin{tabular}{|l|}
0.55 \\
\end{tabular} & 6.5 & 63.8185 & 1361.4 & & 1383.41 & \\
\hline 2 & \begin{tabular}{|l|}
0.55 \\
\end{tabular} & 6.5 & 84 & \begin{tabular}{|l|}
1494.09 \\
\end{tabular} & & 1493.13 & \\
\hline 3 & \begin{tabular}{|l|}
1.30681 \\
\end{tabular} & 6.5 & 84 & 1393.25 & & 1377.92 & \\
\hline 4 & 1 & 4 & 96 & 1208.53 & & 1261.8 & \\
\hline 5 & \begin{tabular}{|l|}
0.1 \\
\end{tabular} & 9 & 96 & 1376.31 & & 1357.27 & \\
\hline 6 & \begin{tabular}{|l|}
0.55 \\
\end{tabular} & 6.5 & 84 & \begin{tabular}{|l|}
1499.09 \\
\end{tabular} & & 1493.13 & \\
\hline 7 & \begin{tabular}{|l|}
-0.206807 \\
\end{tabular} & 6.5 & 84 & \begin{tabular}{|l|}
1149.9 \\
\end{tabular} & & 1121.13 & \\
\hline 8 & \begin{tabular}{|l|}
0.1 \\
\end{tabular} & 4 & 72 & 1143.66 & & 1117.8 & \\
\hline 9 & 1 & 4 & 72 & 1340.89 & & 1320.4 & \\
\hline 10 & \begin{tabular}{|l|}
0.55 \\
\end{tabular} & 2.29552 & 84 & 1084.68 & & 1107.76 & \\
\hline 11 & \begin{tabular}{|l|}
0.55 \\
\end{tabular} & 6.5 & 104.182 & 1423.51 & & 1457.4 & \\
\hline 12 & \begin{tabular}{|l|}
0.55 \\
\end{tabular} & 6.5 & 84 & \begin{tabular}{|l|l|}
1490.11 \\
\end{tabular} & & 1493.13 & \\
\hline 13 & \begin{tabular}{|l|}
0.55 \\
\end{tabular} & 6.5 & 84 & 1493.56 & & 1493.13 & \\
\hline 14 & \begin{tabular}{|l|}
0.1 \\
\end{tabular} & 4 & 96 & 1193.94 & & 1162.15 & \\
\hline 15 & \begin{tabular}{|l|l|l|}
1 & \\
\end{tabular} & 9 & 72 & \begin{tabular}{|l|l|}
1478.17 \\
\end{tabular} & & 1416.43 & \\
\hline 16 & \begin{tabular}{|l|}
0.55 \\
\end{tabular} & 10.7045 & 84 & \begin{tabular}{|l|l|}
1319.77 \\
\end{tabular} & & 1352.59 & \\
\hline
\end{tabular}




\begin{tabular}{l|l|l|l|l|l}
\cline { 3 - 6 } Run & Yeast Extract & $\mathbf{p H}$ & Fermentation period & \multicolumn{2}{|l}{ Response (Y) } \\
\cline { 4 - 7 } & & & & $\begin{array}{l}\text { Enzyme Activity } \\
(\mathbf{U} / \mathbf{m L})\end{array}$ & $\begin{array}{l}\text { Predicted } \\
(\mathbf{U} / \mathbf{m L})\end{array}$ \\
\hline 17 & 1 & 9 & 96 & 1573.72 & 1460.05 \\
\hline 18 & 0.55 & 6.5 & 72 & 1497.23 & 1493.13 \\
\hline 19 & 0.1 & 9 & 84 & 1183.49 & 1210.69 \\
\hline 20 & 0.55 & 6.5 & & 1494.3 & 1493.13
\end{tabular}

Table 6. ANOVA for response surface methodology.

\begin{tabular}{l|l|l|l|l|l|l} 
Source & Sum of Squares & Df & Mean Square & F Value & Prob $>$ F & \\
\hline Model & $4.169 \mathrm{E}+005$ & 9 & 46321.04 & 61.56 & $<0.0001$ & significant \\
\hline A-Yeast Extract & 90735.17 & 1 & 90735.17 & 120.59 & $<0.0001$ & \\
\hline $\mathrm{B}-\mathrm{pH}$ & 91858.31 & 1 & 91858.31 & 122.08 & $<0.0001$ & \\
\hline $\mathrm{C}-$ Fermentation Period & 7070.67 & 1 & 7070.67 & 9.40 & 0.0119 & \\
\hline $\mathrm{AB}$ & 9818.91 & 1 & 9818.91 & 13.05 & 0.0047 & \\
\hline $\mathrm{AC}$ & 9793.70 & 1 & 9793.70 & 13.02 & 0.0048 & \\
\hline $\mathrm{BC}$ & 17154.15 & 1 & 17154.15 & 22.80 & 0.0008 & \\
\hline $\mathrm{A}^{2}$ & 73227.78 & 1 & 73227.78 & 97.32 & $<0.0001$ & \\
\hline $\mathrm{B}^{2}$ & $1.323 \mathrm{E}+005$ & 1 & $1.323 \mathrm{E}+005$ & 175.79 & $<0.0001$ & \\
\hline $\mathrm{C}^{2}$ & 11743.02 & 1 & 11743.02 & 15.61 & 0.0027 & \\
\hline Residual & 7524.34 & 10 & 752.43 & & & \\
\hline Lack of Fit & $1.328 \mathrm{E}+005$ & 5 & $2.656 \mathrm{E}+022$ & 2.73 & 0.756 & Not significant \\
\hline Pure Error & $4.85 \mathrm{E}+07$ & 5 & 9.71 & & &
\end{tabular}

The response (Y) was well correlated with a quadratic second-order polynomial equation. The final equation in terms of coded factors:

Enzyme Activity

$$
\begin{aligned}
& =+494.0+70.35 * \mathrm{~A}+146.41 * \mathrm{~B}-122.69 * \mathrm{C}+71.04 * \mathrm{AB}-2.63 \\
& * \mathrm{~A}-76.44 * \mathrm{BC}-133.46 * \mathrm{~A} 2-86.35 * \mathrm{~B} 2-86.32 * \mathrm{C} 2
\end{aligned}
$$

The 3D surface plots show the impact of the interaction of two variables for the enzyme production while the third one is kept as a zero-coded level (Figure 4 (a-c)). Among the variables used in $\mathrm{CCD}$, yeast extract and $\mathrm{pH}$ significantly affect enzyme production compared with the other variables. The perturbation plot represents that the factors fermentation period, $\mathrm{pH}$, and yeast extract have a vital role in enzyme production. Comparing the previous OFAT (43.7 U/mL) optimization, the enzyme's synthesis has increased fifteen-fold to the enzyme activity $678.17 \mathrm{U} / \mathrm{mL}$ in the RSM. Similarly, the validated experimental results conducted with the optimized conditions show that the enzyme production was $678.17 \mathrm{U} / \mathrm{mL}$. It shows a good agreement with that of the predicted value that validates the model design.

\subsection{Separation and partial purification of the protease.}

The extracellular protease from Brevundimonas diminuta VKB1 was partially purified, as shown in Table 7. Specific activity was calculated at each step of purification by the obtained enzyme activity and protein concentration. It was observed that the gel filtration purified enzyme was showing 5.4-fold activity comparing the crude protein content, and the protein recovery was near $53.92 \%$. The protein's molecular weight was determined by SDS-PAGE, which showed protein bands with a mass value of $\sim 25 \mathrm{kDa}$ (Figure 5 (a)). 


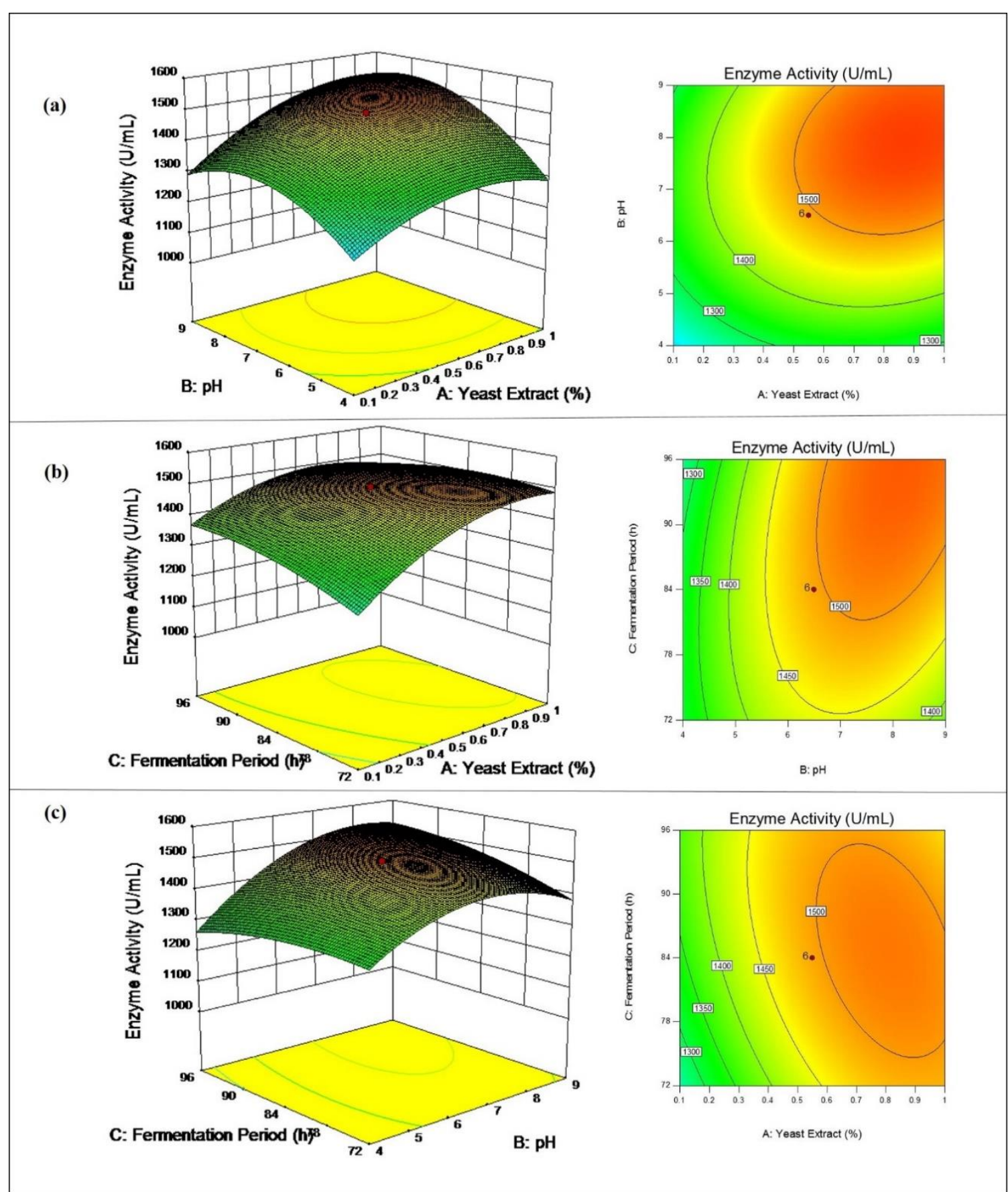

Figure 4. 3D surface representation of the RSM analysis. (a) shows elliptical contour plots indicating significant interactions among yeast extract and $\mathrm{pH}$; (b) shows elliptical plots revealing moderate interaction among fermentation period and yeast extract; (c) also showing elliptical plots with high interactions among fermentation period and $\mathrm{pH}$.

Also, according to the results of HPLC, the partially purified enzyme was showing two peaks. As the protein peaks were merged, it was assumed that they could be a single protein that might get degraded. The efficiency of purified protease in protein degradation using fibrin and casein as substrate was performed, and the zone of degradation was observed (Figure 5 ((b) and (c)). 
(a)

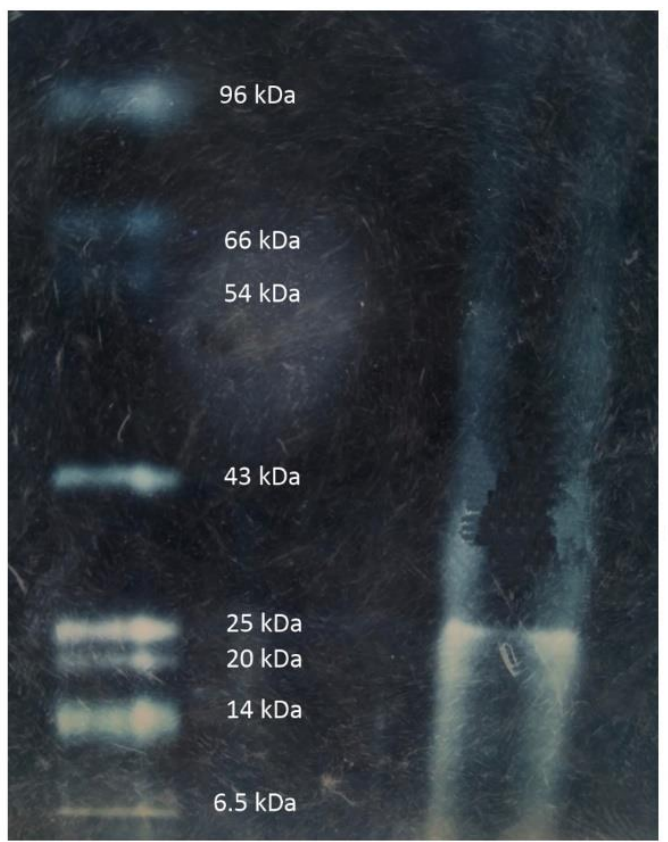

(b)

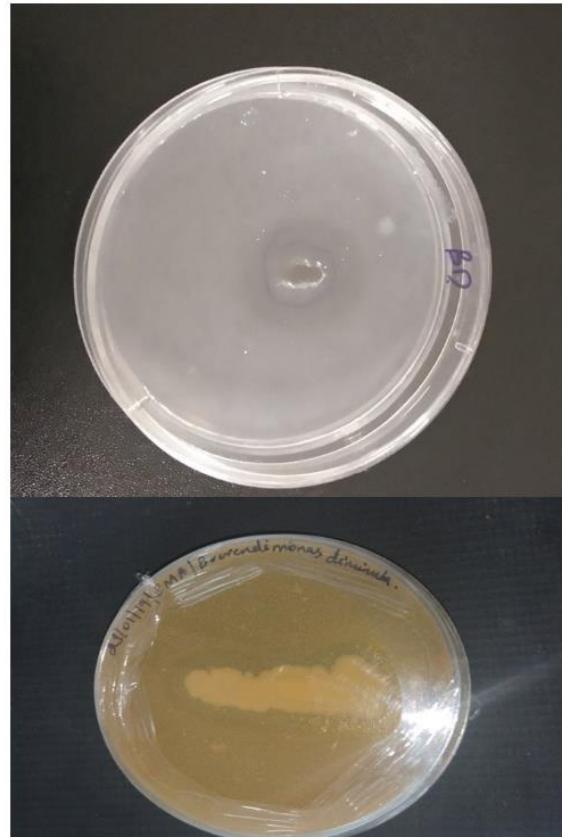

Figure 5. Molecular weight determination and protein degradation. (a) SDS-PAGE analysis revealing the approximate molecular weight of the protease purified using marker lane; (b) zone of degradation appeared after incubating the substrate fibrin with protease overnight using fibrin plate assay; (c) zone of degradation appeared after incubating the substrate casein with protease overnight using skim milk agar plate.

\begin{tabular}{|c|c|c|c|c|c|}
\hline Purification steps & $\begin{array}{l}\text { Total Protein } \\
(\mu \mathrm{g} / \mathrm{mL})\end{array}$ & $\begin{array}{l}\text { Total activity } \\
(\mathrm{U} / \mathrm{mL})\end{array}$ & $\begin{array}{l}\text { Specific Activity } \\
\text { (U/mg) }\end{array}$ & Recovery (\%) & $\begin{array}{l}\text { Purification } \\
\text { fold }\end{array}$ \\
\hline Crude Extract & 956 & 157.6 & 164.81 & 100 & 1 \\
\hline $\begin{array}{ll}\text { Ammonium } & \text { Sulphate } \\
\text { Precipitation } & \end{array}$ & 728 & 131.40 & 180.50 & 83.37 & 1.09 \\
\hline Dialysis & 443 & 127.83 & 288.57 & 81.11 & 1.75 \\
\hline $\begin{array}{l}\text { Ion-Exchange } \\
\text { Chromatography }\end{array}$ & 225 & 96.9 & 430.75 & 61.50 & 2.61 \\
\hline Sephadex G-100 & 95 & 84.96 & 894.39 & 53.92 & 5.4 \\
\hline
\end{tabular}

\subsection{Biochemical properties of the purified enzyme.}

The effect of $\mathrm{pH}$ on the protease activity was determined (Figure 6 (a)), and the results depicted that the enzyme was highly active at $\mathrm{pH}$ 7-8. In general, the protease enzymes are active at neutral and alkaline $\mathrm{pH}$ conditions with an optimum $\mathrm{pH}$ of 8 and 10 [24,40]. The enzyme activity was dropdown below $\mathrm{pH}$ 6. Thus, the purified enzyme was assumed to be an alkaline protease. As per temperature, the enzyme showed higher stability till $40{ }^{\circ} \mathrm{C}$ and the activity dropdown at $60{ }^{\circ} \mathrm{C}$ (Figure 6 (b)).
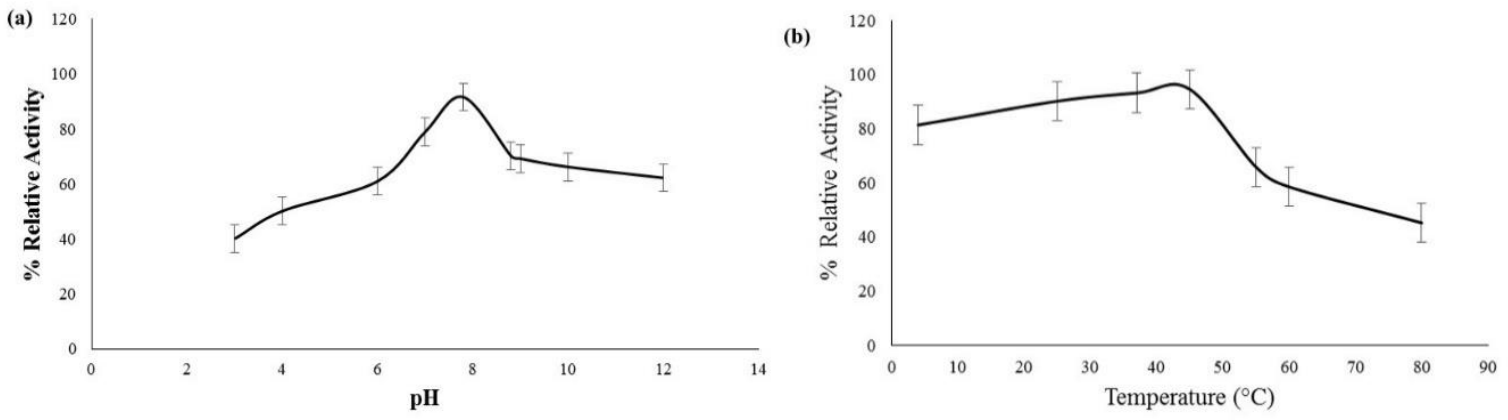

Figure 6. Various analyses performed to understand the purified protease stability. (a) effect of pH on enzyme activity; (b) effect of temperature on enzyme activity. 
The enzyme activity was determined with inhibitors; it was shown that the inhibitors PMSF and DTPA showed less enzyme activity whose relative activity percentage was $80.50 \%$ and $75.66 \%$ comparing the EDTA and Pepstatin A (95.82\% and 85.86\%). The results indicate that the enzyme belongs to the serine protease class. Also, the enzyme was showing high relative activity percentage with the metals $\mathrm{Cu}^{+}, \mathrm{Mg}^{+}, \mathrm{Fe}^{+}$, comparing the other metals $\mathrm{Ca}^{+}$and $\mathrm{Zn}^{+}$(Table 8). Hence from the biochemical characterization, the enzyme shows excellent stability by confirming their productive enzyme activity comparing the other proteases produced by other bacterium sources $[42,47,48]$.

Table 8. Effect of protein inhibitors and metal ions towards the VKB1 enzyme activity.

\begin{tabular}{l|l} 
Inhibitors (5 mM) & Relative activity $(\%)$ \\
\hline PMSF & 80.50 \\
\hline DTPA & 75.66 \\
\hline EDTA & 95.82 \\
\hline Pepstatin A & 85.86 \\
\hline $\mathrm{CaCl}_{2}$ & 72.80 \\
\hline $\mathrm{MgSO}_{4}$ & 84.68 \\
\hline $\mathrm{MnSO}_{4}$ & 88.48 \\
\hline $\mathrm{FeSO}_{4}$ & 90.66 \\
\hline $\mathrm{ZnSO}_{4}$ & 95.90 \\
\hline $\mathrm{ZSO}_{4}$ & 67.74
\end{tabular}

\subsection{Discussion.}

This study's significant aspect is the production of thermostable protease from the endophytic strain Brevundimonas diminuta VKB1 host in Carica papaya L fruit. The industrially-produced large-scale level of protease enzymes is predominantly from the Bacillus species. The commercially available Subtilase, Nattokinase, Savinase are produced by the Bacillus subtilisin, Bacillus natto, and Bacillus lentus [49]. Protease from Brevundimonas diminuta was not highly reported. Out of fifteen isolates, strain VKB1 showed high extracellular proteolytic activity and selected for further studies. If two bacteria shared $99 \%$ homology in their 16s rRNA sequence are found to be in the same genus. The strain VKB1 was identified through 16s rRNA sequencing and share 99\% homology with both Alpha proteobacterium and Brevundimonas diminuta. However, the Brevundimonas diminuta and Brevundimonas species located in other clades also showed above $92 \%$ similarly defines that the strain belongs to the Brevundimonas diminuta genus.

Enhancement of the protease production through medium components was formulated based on classical and statistical optimization techniques. The medium components for protease production differ from microbes to microbes. Hence the conventional OFAT approach was first examined to find out the significant factors from each variable. As a disaccharide, maltose followed by sucrose and galactose influences the high enzyme activity comparing the 'monosaccharides [29,50,51]. This is because of their readily metabolizing nature and limited availability [27,52]. Yeast extract and sodium dihydrogen phosphate were found to be more efficient in the synthesis of the enzyme. Nitrogen sources are generally utilized for their role in the synthesis of cell components, amino acids, etc. [10,22]. Physical factors influence the growth condition of bacteria to grow in its adaptive condition. Upon optimization, the VKB1 strain utilized maltose, yeast extract, and sodium di-hydrogen phosphate under $\mathrm{pH} 8$ at $37^{\circ} \mathrm{C}$ with $100 \mathrm{rpm}$ incubated for $72 \mathrm{~h}$ for the enhanced protease production.

The statistical method of optimization helps scrutinize the main and significant factors for their influence and interaction in enzyme production. They are cheaper and time-consuming comparing the OFAT approach. Plackett-Burman Design was followed in this study to initiate 
the selection of critically significant factors necessary for the next Response Surface Methodology. Among the six variables from the OFAT approach, the design exhibited yeast extract, $\mathrm{pH}$, and incubation time as significant, influencing the protease production's positive effect. PB design lags the exact quantification of factors needed for the production and does not define the interactive response among variables. Hence RSM was carried out to perform the interaction among variables using CCD. The 3D representation exaggerates the regression analysis of the interacting variables at an optimum level. The $2 \mathrm{D}$ contour plots with the elliptical design depict the significant interaction and circular for the non-significant interaction among the variables. The study plots that yeast extract's interaction: $\mathrm{pH}$ and $\mathrm{pH}$ : incubation time showing the significant influence on protease production comparing the yeast extract: incubation time. The results show that the depletion in yeast extract concentration with increasing fermentation period decreases the enzyme production leading to non-significant results. The purified protease characterization enlightens that it can be serine alkaline protease that withstands a high-temperature environment. The involvement of metal ions in the enzyme activity widely helps understand the enzyme's nature, whether it can be a metalloprotease or not. Further, metal ions highly stabilize the enzyme acting as a cofactor. Hence, copper metal ion plays a major role in influencing enzyme activity, followed by iron and magnesium. Though it is not a metalloprotease, the above trace metal ions are highly reported as a cofactor for various proteins, defining that they can be acting as a cofactor for the purified enzyme. Further studies on understanding the molecular nature and purity of the protease through SDS PAGE and HPLC analysis determines that the protein is not stable under detergents and they degrade so easily because the bands appear to be a single protein of the same molecular weight depicting, they can be a single protein of molecular weight $\sim 25 \mathrm{kDa}$.

\section{Conclusion}

The study highlights that the purified protease from endophyte shows thermo-stability at a higher temperature and alkaline protease. The protease's enhanced production from the endophyte Brevundimonas diminuta VKB1 hosted in unripe fruit Carica papaya L. depicts that the production was increase fifteen-fold at the stage of response surface methodology comparing the OFAT. The influence of the copper and other divalent metal ions acting as a cofactor for the enzyme activity defines that the protease can be an antioxidant enzyme. Further studies on the protease towards their biological activity may throw light on the therapeutic properties.

\section{Funding}

This research received no external funding.

\section{Acknowledgments}

I would like to thank VIT University for providing seed grants and laboratory facilities to carry out this research work.

\section{Conflicts of Interest}

The authors declare that they have no conflict of interest. 


\section{References}

1. Khan, A.L.; Shahzad, R.; Al-Harrasi, A.; Lee, I.-J. Endophytic Microbes: A Resource for Producing Extracellular Enzymes. In Endophytes: Crop Productivity and Protection: Volume 2, Maheshwari, D.K., Annapurna, K., Eds. Springer International Publishing: Cham, 2017, https://doi.org/10.1007/978-3-31966544-3.

2. Ben Mefteh, F.; Frikha, F.; Daoud, A.; Chenari Bouket, A.; Luptakova, L.; Alenezi, F.N.; Al-Anzi, B.S.; Oszako, T.; Gharsallah, N.; Belbahri, L. Response Surface Methodology Optimization of an Acidic Protease Produced by Penicillium bilaiae Isolate TDPEF30, a Newly Recovered Endophytic Fungus from Healthy Roots of Date Palm Trees (Phoenix dactylifera L.). Microorganisms 2019, 7 , https://doi.org/10.3390/microorganisms7030074.

3. Anu, C.J.; Christy, P.H.; Jijo, C.J. Production and purification of cellulase enzyme by endophytic Bacillus sp. isolated from Rhizophora mucronata. International Journal of Agriculture, Environment and Biotechnology 2014, 7, 367, https://doi.org/10.5958/2230-732x.2014.00257.5.

4. Ek-Ramos, M.J.; Gomez-Flores, R.; Orozco-Flores, A.A.; Rodríguez-Padilla, C.; González-Ochoa, G.; Tamez-Guerra, P. Bioactive Products From Plant-Endophytic Gram-Positive Bacteria. Front. Microbiol. 2019, 10, 463, https://doi.org/10.3389/fmicb.2019.00463.

5. Castro, R.A.; Quecine, M.C.; Lacava, P.T.; Batista, B.D.; Luvizotto, D.M.; Marcon, J.; Ferreira, A.; Melo, I.S.; Azevedo, J.L. Isolation and enzyme bioprospection of endophytic bacteria associated with plants of Brazilian mangrove ecosystem. SpringerPlus 2014, 3, 382, https://doi.org/10.1186/2193-1801-3-382.

6. Abhini, K.N.; Fathimathu Zuhara, K. Isolation Screening and Identification of Bacterial Endophytes from Medicinal Plants as a potential source of L-Asparaginase Enzyme. J. Chem. Pharm. Sci. 2018, 11, 73-76, https://doi.org/10.30558/jchps.20181101014.

7. Stamford, T.L.M.; Stamford, N.P.; Coelho, L.C.B.B.; Araújo, J.M. Production and characterization of a thermostable glucoamylase from Streptosporangium sp. endophyte of maize leaves. Bioresour. Technol. 2002, 83, 105-109, https://doi.org/10.1016/S0960-8524(01)00206-1.

8. Lu, F.; Lu, Z.; Bie, X.; Yao, Z.; Wang, Y.; Lu, Y.; Guo, Y. Purification and characterization of a novel anticoagulant and fibrinolytic enzyme produced by endophytic bacterium Paenibacillus polymyxa EJS-3. Thromb. Res. 2010, 126, e349-e355, https://doi.org/10.1016/j.thromres.2010.08.003.

9. Vijayaraghavan, P.; Prakash Vincent, S.G. Medium Optimization for the Production of Fibrinolytic Enzyme by Paenibacillus Sp. IND8 Using Response Surface Methodology. The Scientific World Journal 2014, 2014, 276942, https://doi.org/10.1155/2014/276942.

10. Krishnan, P.; Bhat, R.; Kush, A.; Ravikumar, P. Isolation and functional characterization of bacterial endophytes from Carica papaya fruits. J. Appl. Microbiol. 2012, 113, 308-317, https://doi.org/10.1111/j.13652672.2012.05340.x.

11. Vij, T.; Prashar, Y. A review on medicinal properties of Carica papaya Linn. Asian Pacific Journal of Tropical Disease 2015, 5, 1-6, https://doi.org/10.1016/S2222-1808(14)60617-4.

12. Pendzhiev, A.M. Proteolytic Enzymes of Papaya: Medicinal Applications. Pharm. Chem. J. 2002, 36, 315317, https://doi.org/10.1023/A:1020832807958.

13. Dhivya, R.; Rashma, R.S.; Vinothini, B.; Pavithra, R. Extraction and purification of papain enzyme from carica papaya for wound debridement. International Journal of Pure and Applied Mathematics 2018, 119, 1265-1274.

14. andAbebe Worku, Y.W. Identification and extraction of papain enzyme from papaya leaf in adigrat towen, northern Ethiopia. Journal of Medicinal Plants 2018, 6, 127-130.

15. Meshram, A.; Singhal, G.; Bhagyawant, S.S.; Srivastava, N. Chapter 28 - Plant-Derived Enzymes: A Treasure for Food Biotechnology. In Enzymes in Food Biotechnology, Kuddus, M., Ed. Academic Press: 2019, https://doi.org/10.1016/B978-0-12-813280-7.00028-1.

16. Razzaq, A.; Shamsi, S.; Ali, A.; Ali, Q.; Sajjad, M.; Malik, A.; Ashraf, M. Microbial Proteases Applications. Frontiers in Bioengineering and Biotechnology 2019, 7, 110, https://doi.org/10.3389/fbioe.2019.00110.

17. Chanalia, P.; Gandhi, D.; Jodha, D.; Singh, J. Applications of microbial proteases in pharmaceutical industry: an overview. Rev. Med. Microbiol. 2011, 22, https://doi.org/10.1097/MRM.0b013e3283494749.

18. Suleiman, A.D.; Abdul Rahman, N.A.; Mohd Yusof, H.; Mohd Shariff, F.; Yasid, N.A. Effect of Cultural Conditions on Protease Production by a Thermophilic Geobacillus thermoglucosidasius SKF4 Isolated from Sungai Klah Hot Spring Park, Malaysia. Molecules 2020, 25, https://doi.org/10.3390/molecules25112609.

19. Shweta, S.; Bindu, J.H.; Raghu, J.; Suma, H.K.; Manjunatha, B.L.; Kumara, P.M.; Ravikanth, G.; Nataraja, K.N.; Ganeshaiah, K.N.; Uma Shaanker, R. Isolation of endophytic bacteria producing the anti-cancer 
alkaloid camptothecine from Miquelia dentata Bedd. (Icacinaceae). Phytomedicine 2013, 20, 913-917, https://doi.org/10.1016/j.phymed.2013.04.004.

20. Suhandono, S.; Kusumawardhani, M.K.; Aditiawati, P. Isolation and Molecular Identification of Endophytic Bacteria From Rambutan Fruits (Nephelium lappaceum L.) Cultivar Binjai. HAYATI Journal of Biosciences 2016, 23, 39-44, https://doi.org/10.1016/j.hjb.2016.01.005.

21. Abu-Khudir, R.; Salem, M.M.; Allam, N.G.; Ali, E.M.M. Production, Partial Purification, and Biochemical Characterization of a Thermotolerant Alkaline Metallo-protease from Staphylococcus sciuri. Appl. Biochem. Biotechnol. 2019, 189, 87-102, https://doi.org/10.1007/s12010-019-02983-6.

22. Marathe, S.K.; Vashistht, M.A.; Prashanth, A.; Parveen, N.; Chakraborty, S.; Nair, S.S. Isolation, partial purification, biochemical characterization and detergent compatibility of alkaline protease produced by Bacillus subtilis, Alcaligenes faecalis and Pseudomonas aeruginosa obtained from sea water samples. Journal of Genetic Engineering and Biotechnology 2018, 16, 39-46, https://doi.org/10.1016/j.jgeb.2017.10.001.

23. Agrebi, R.; Haddar, A.; Hmidet, N.; Jellouli, K.; Manni, L.; Nasri, M. BSF1 fibrinolytic enzyme from a marine bacterium Bacillus subtilis A26: Purification, biochemical and molecular characterization. Process Biochem. 2009, 44, 1252-1259, https://doi.org/10.1016/j.procbio.2009.06.024.

24. Sharma, K.M.; Kumar, R.; Panwar, S.; Kumar, A. Microbial alkaline proteases: Optimization of production parameters and their properties. Journal of Genetic Engineering and Biotechnology 2017, 15, 115-126, https://doi.org/10.1016/j.jgeb.2017.02.001.

25. Khusro, A.; Barathikannan, K.; Aarti, C.; Agastian, P. Optimization of Thermo-Alkali Stable Amylase Production and Biomass Yield from Bacillus sp. Under Submerged Cultivation. Fermentation 2017, 3, https://doi.org/10.3390/fermentation3010007.

26. Vijayaraghavan, P.; Arasu, M.V.; Anantha Rajan, R.; Al-Dhabi, N.A. Enhanced production of fibrinolytic enzyme by a new Xanthomonas oryzae IND3 using low-cost culture medium by response surface methodology. Saudi J. Biol. Sci. 2019, 26, 217-224, https://doi.org/10.1016/j.sjbs.2018.08.029.

27. Abdullah Al-Dhabi, N.; Ali Esmail, G.; Mohammed Ghilan, A.-K.; Valan Arasu, M.; Duraipandiyan, V.; Ponmurugan, K. Characterization and fermentation optimization of novel thermo stable alkaline protease from Streptomyces sp. Al-Dhabi-82 from the Saudi Arabian environment for eco-friendly and industrial applications. Journal of King Saud University - Science 2020, 32, 1258-1264, https://doi.org/10.1016/j.jksus.2019.11.011.

28. Patil, N.S.; Kurhekar, J.V. Optimization of Protease Production by Bacillus isronensis Strain KD3 Isolated from Dairy Industry Effluent. Nature Environment \& Pollution Technology 2020, 19, https://doi.org/10.46488/NEPT.2020.v19i03.041.

29. Anson, M.L. THE ESTIMATION OF PEPSIN, TRYPSIN, PAPAIN, AND CATHEPSIN WITH HEMOGLOBIN. J. Gen. Physiol. 1938, 22, 79-89, https://doi.org/10.1085/jgp.22.1.79.

30. Lowry, O.H.; Rosebrough, N.J.; Farr, A.L.; Randall, R.J. Protein measurement with the Folin phenol reagent. J. Biol. Chem. 1951, 193, 265-275.

31. Sai-Ut, S.; Benjakul, S.; Sumpavapol, P.; Kishimura, H. Optimization of gelatinolytic enzyme production by B. amyloliquefaciens sp. H11 through Plackett-Burman design and response surface methodology. International Aquatic Research 2014, 6, 59, https://doi.org/10.1007/s40071-014-0059-5.

32. Jabeur, F.; Mechri, S.; Kriaa, M.; Gharbi, I.; Bejaoui, N.; Sadok, S.; Jaouadi, B. Statistical Experimental Design Optimization of Microbial Proteases Production under Co-Culture Conditions for Chitin Recovery from Speckled Shrimp Metapenaeus Monoceros By-Product. BioMed Research International 2020, 2020, 3707804, https://doi.org/10.1155/2020/3707804.

33. Reddy, L.V.A.; Wee, Y.-J.; Yun, J.-S.; Ryu, H.-W. Optimization of alkaline protease production by batch culture of Bacillus sp. RKY3 through Plackett-Burman and response surface methodological approaches. Bioresour. Technol. 2008, 99, 2242-2249, https://doi.org/10.1016/j.biortech.2007.05.006.

34. Shabbiri, K.; Adnan, A.; Jamil, S.; Ahmad, W.; Noor, B.; Rafique, H.M. Medium optimization of protease production by Brevibacterium linens DSM 20158, using statistical approach. Braz. J. Microbiol. 2012, 43, 1051-1061, https://doi.org/10.1590/S1517-83822012000300031.

35. Mukherjee, A.K.; Rai, S.K. A statistical approach for the enhanced production of alkaline protease showing fibrinolytic activity from a newly isolated Gram-negative Bacillus sp. strain AS-S20-I. N. Biotechnol. 2011, 28, 182-189, https://doi.org/10.1016/j.nbt.2010.11.003.

36. Majumdar, S.; Goswami, S.; Keppen, C.; Rai, S.K.; Mukherjee, A.K. Statistical optimization for improved production of fibrin(Ogen)olytic enzyme by Bacillus cereus strain FF01 and assessment of in vitro 
thrombolytic potential of protease enzyme. Biocatalysis and Agricultural Biotechnology 2015, 4, 191-198, https://doi.org/10.1016/j.bcab.2014.11.004.

37. Vijayaraghavan, P.; Vincent, S.G.P. Statistical optimization of fibrinolytic enzyme production by Pseudoalteromonas sp. IND11 using cow dung substrate by response surface methodology. SpringerPlus 2014, 3, 60, https://doi.org/10.1186/2193-1801-3-60.

38. Peng, Y.; Huang, Q.; Zhang, R.-h.; Zhang, Y.-z. Purification and characterization of a fibrinolytic enzyme produced by Bacillus amyloliquefaciens DC-4 screened from douchi, a traditional Chinese soybean food. Comparative Biochemistry and Physiology Part B: Biochemistry and Molecular Biology 2003, 134, 45-52, https://doi.org/10.1016/S1096-4959(02)00183-5.

39. Meshram, V.; Saxena, S. Potential fibrinolytic activity of an endophytic Lasiodiplodia pseudotheobromae species. 3 Biotech 2016, 6, 114, https://doi.org/10.1007/s13205-016-0428-4.

40. Bhardwaj, P.; Anjum, S.; Dahiya, P. Purification And Characterization Of Novel Solvent Stable Bacillus Cereus Pi-C4 Protease From Poultry Waste. Journal of Microbiology, Biotechnology and Food Sciences 2020, 2020, 865-869, https://doi.org/10.15414/jmbfs.2020.9.5.865-869.

41. Vijayaraghavan, P.; Prakash Vincent, S.G. A low cost fermentation medium for potential fibrinolytic enzyme production by a newly isolated marine bacterium, Shewanella sp. IND20. Biotechnology Reports 2015, 7, 135-142, https://doi.org/10.1016/j.btre.2015.06.005.

42. Devaraj, Y.; Rajender, S.K.; Halami, P.M. Purification and characterization of fibrinolytic protease from Bacillus amyloliquefaciens MCC2606 and analysis of fibrin degradation product by MS/MS. Prep. Biochem. Biotechnol. 2018, 48, 172-180, https://doi.org/10.1080/10826068.2017.1421964.

43. Thomas, N.N.; Archana, V.; Shibina, S.; Edwin, B.T. Isolation and characterization of a protease from Bacillus sps. Materials Today: Proceedings 2020, https://doi.org/10.1016/j.matpr.2020.05.435.

44. Ji, Z.-L.; Peng, S.; Chen, L.-L.; Liu, Y.; Yan, C.; Zhu, F. Identification and characterization of a serine protease from Bacillus licheniformis W10: A potential antifungal agent. Int. J. Biol. Macromol. 2020, 145, 594-603, https://doi.org/10.1016/j.ijbiomac.2019.12.216.

45. Khursade, P.S.; Galande, S.H.; Shiva Krishna, P.; Prakasham, R.S. Stenotrophomonas maltophilia Gd2: A potential and novel isolate for fibrinolytic enzyme production. Saudi J. Biol. Sci. 2019, 26, 1567-1575, https://doi.org/10.1016/j.sjbs.2018.10.014.

46. Montriwong, A.; Kaewphuak, S.; Rodtong, S.; Roytrakul, S.; Yongsawatdigul, J. Novel fibrinolytic enzymes from Virgibacillus halodenitrificans SK1-3-7 isolated from fish sauce fermentation. Process Biochem. 2012, 47, 2379-2387, https://doi.org/10.1016/j.procbio.2012.09.020.

47. Huang, S.; Pan, S.; Chen, G.; Huang, S.; Zhang, Z.; Li, Y.; Liang, Z. Biochemical characteristics of a fibrinolytic enzyme purified from a marine bacterium, Bacillus subtilis HQS-3. Int. J. Biol. Macromol. 2013, 62, 124-130, https://doi.org/10.1016/j.ijbiomac.2013.08.048.

48. Liu, Q.; Sun, S.; Piao, M.; Yang, J.Y. Purification and Characterization of a Protease Produced by a Planomicrobium sp. L-2 from Gut of Octopus vulgaris. Preventive nutrition and food science 2013, 18, 273, https://doi.org/10.3746/pnf.2013.18.4.273.

49. Jhample, S.B.; Bhagwat, P.K.; Dandge, P.B. Statistical media optimization for enhanced production of fibrinolytic enzyme from newly isolated Proteus penneri SP-20. Biocatalysis and Agricultural Biotechnology 2015, 4, 370-379, https://doi.org/10.1016/j.bcab.2015.05.006.

50. Ju, S.; Cao, Z.; Wong, C.; Liu, Y.; Foda, M.F.; Zhang, Z.; Li, J. Isolation and Optimal Fermentation Condition of the Bacillus subtilis Subsp. natto Strain WTC016 for Nattokinase Production. Fermentation 2019, 5 , https://doi.org/10.3390/fermentation5040092.

51. Akcan, N. Production of extracellular protease in submerged fermentation by Bacillus licheniformis ATCC 12759. AFRICAN JOURNAL OF BIOTECHNOLOGY 2012, 11, https://doi.org/10.5897/AJB11.2183.

52. Bhunia, B.; Dutta, D.; Chaudhuri, S. Selection of suitable carbon, nitrogen and sulphate source for the production of alkaline protease by Bacillus licheniformis NCIM-2042. Notulae Scientia Biologicae 2010, 2, 56-59, https://doi.org/10.15835/nsb224630. 